\title{
The reception of Chalcedon in the West: a case study of Gregory the Great
}

\author{
Janet Sidaway \\ King's College London, Strand Campus, London, UK \\ ${ }^{*}$ Corresponding author. jsidawayxx@gmail.com
}

\begin{abstract}
Gregory illustrates the complex reception of Chalcedon in the West in the way he dealt with the Istrian Schism caused by the Fifth Ecumenical Council of 553. At issue was whether Chalcedon's decisions in their entirety or its doctrinal statements alone were inviolable. Gregory strongly urged the latter, influenced by initial papal support for the Fifth Council, his conviction that only those within the church would be saved and pastoral anxiety about the imminence of the eschaton. However, his literary legacy also demonstrates his commitment to the soteriological significance of the Chalcedonian definition of the two natures of Christ.
\end{abstract}

Keywords: Aquileia; Chalcedon; Gregory the Great; Istrian Schism; Pelagius II; Three Chapters

The longer term impact of the Council of Chalcedon (451) is receiving increasing attention as modern scholars reassess how interpretation of its definitions evolved to absorb new theological developments, while trying to maintain its status as the unchangeable reference point of christological doctrine. But most attention has been paid to the complex development of 'Neo-Chalcedonianism' in the East, before and after the Fifth Ecumenical Council held in Constantinople in 553. Reception in the West has been comparatively neglected, perhaps under the influence of Aloys Grillmeier, who in 1987 stated: 'Between 553 and 604 we find the West united in a single-minded but uncomplicated trust in Chalcedon.' ${ }^{\prime}$ My purpose in this article is to show through the writings of Gregory the Great (born c.540, pope 590-604) that the reception of Chalcedon was far from 'single-minded' and 'uncomplicated'. As Gregory himself is not well known to nonspecialists, I hope that the article will also stimulate more general interest in his life and work, and the way in which these were shaped by a complex concatenation of external threats and theological controversy closely linked to Chalcedon.

\section{Personal history}

Gregory's attitude to Chalcedon must be seen in the context of the devastating situation of Italy in his lifetime, although at a personal level he had the relative advantage of

\footnotetext{
${ }^{1}$ Aloys Grillmeier in collaboration with Theresia Hainthaler, From the Council of Chalcedon (451) to Gregory the Great (590-604), vol. 2 of Christ in the Christian Tradition, trans. Pauline Allen and John Cawte (London: Mowbray, 1987), p. 14.

(C) The Author(s), 2021. Published by Cambridge University Press. This is an Open Access article, distributed under the terms of the Creative Commons Attribution licence (http://creativecommons.org/licenses/by/4.0/), which permits unrestricted re-use, distribution, and reproduction in any medium, provided the original work is properly cited.
} 
belonging to a wealthy Christian family in Rome and receiving a traditional classical education. He seems to have been the only member of his family to have had a secular career: one of his ancestors had also been a pope (Felix III, r. 526-30). By 573 he had become Prefect of the City, but soon afterwards he abandoned civic office and became a monk, giving away most of the family properties he had inherited. Around 578 he was persuaded by the then pope, probably already Pelagius II (r. 578/9-590) to take up the post of deacon. Around 579 he was sent by Pelagius as apocrisiarius, or ambassador, to Constantinople, where he stayed until 585/6. In addition to channelling news between the two cities, his main task was to obtain military and financial support from the Emperor (initially Tiberius, then Maurice) to help Rome withstand the attacks of the Lombard invaders.

On the death of Pelagius from the plague in 590, Gregory was elected pope. He was faced with two overwhelming and intertwined challenges: threats to the unity of the church, and the physical as well as the spiritual condition of his flock. His references to Chalcedon were heavily influenced by these challenges, at a practical as well as a pastoral level. This can be seen most clearly in his letters, although his other work gives more information on how he interpreted the theological definition of Christ enshrined in Chalcedon.

Before and during his papacy, Gregory wrote extensively. His literary legacy is vast. It includes a variety of different genres such as exegesis (notably the Moralia in Job), instructions to clergy (the Book of Pastoral Rule) and homilies addressed to wide-ranging audiences from his own monks, bishops and clergy to the people of Rome. He reached an even wider audience with his popular lives of Italian saints (the Dialogues). ${ }^{2}$ His letters are also justly famous. Over 850 letters under his name survive in the papal registry and provide a fascinating insight into the range of issues confronting him, personal as well as professional. ${ }^{3}$

\section{External threats}

The letters record the dire conditions which affected the whole of western Europe in the second half of the sixth century, and also attest to the struggles of the Catholic church itself amidst external attacks and internal threats from heresies and schisms. ${ }^{4}$ The influence of Rome within western Christianity had been greatly diminished by successive invasions of Germanic tribes, either Arian or pagan, through the fifth and sixth centuries. Spain had been conquered by the Arian Visigoths and remained relatively self-contained and independent of Roman influence, although in 587 the new king, Reccared, renounced Arianism for Catholicism. Gaul, ruled since 507 by the Frankish dynasty established by Clovis and his descendants, had maintained its network

\footnotetext{
${ }^{2}$ Robert Markus provides an excellent introduction to the background and life of Gregory in Gregory the Great and his World (Cambridge: Cambridge University Press, 1997). For a chronology and brief description of Gregory's works, see pp. 14-16.

${ }^{3}$ John R. C. Martyn, The Letters of Gregory the Great (Toronto: Pontifical Institute of Medieval Studies, 2004), pp. 13-14. The Latin text is from Gregorii I papae Registrum epistolarum, ed. Paul Ewald and Ludo Moritz Hartmann, Monumenta Germaniae Historica, Epistolae 1-2, 2 vols (Berlin, 1887-99), accessed online. References are given by volume, page and line number. The text of the three letters of Pelagius II are from the Acta Conciliorum Oecumenicorum, vol. 4, ed. E. Schwartz (Berlin: Walter de Gruyter, 1927-82), pp. 105-32. Latin texts from Moralia in Job, the Homilies on Ezekiel and the Gospel Homilies are taken from the relevant Sources Chrétiennes volumes (Paris: Éditions du CERF).

${ }^{4}$ The term 'Catholic' in this article refers to the church represented by the papacy in Rome.
} 
of Gallo-Roman bishops, but Christianity of any sort, let alone the Catholic faith, seems to have been patchy. ${ }^{5}$

Italy itself was split into three areas, with Rome sandwiched between Lombard/ Arian/pagan blocs that often operated independently of each other. Sicily, however, remained within the hegemony of the pope. The Lombards threatened Rome directly in 592/3 and 595 and remained a constant source of anxiety for Gregory. ${ }^{6}$ Imperial help was sometimes promised but rarely delivered. Bubonic plague, endemic since 542, had led to depopulation, meaning little food could be grown, and what little remained was often destroyed or looted by the invaders. In 589 Rome's problems had been compounded by severe flooding of the Tiber. ${ }^{7}$

Gregory's letters show that he worked tirelessly to save Rome from starvation and attack. He used the income from his remaining properties, some of which fortunately were in Sicily, to buy food and to pay the soldiers to protect Rome, while writing frequently but fruitlessly to the emperor and to his representative in Ravenna, the exarch, begging for military help. His main anxiety, however, was spiritual. He believed the various disasters that marked his time presaged the imminent end of the world and the final judgement.

\section{Eschatology}

Gregory's sense of the eschaton was vivid. Brian Daley argues that, with Gregory the Great, 'Latin Patristic eschatology reached its final form' and 'became a principal source for Latin eschatology in the centuries to come. ${ }^{8}$ It has more recently been analysed by Jane Baun. ${ }^{9}$ The anticipated imminence of the last day gave added point to the urgency of Gregory's appeal to his readers and listeners to beware of acting sinfully. In a homily on Ascension Day delivered at some time in 590-2, he reminded his congregation that 'we must consider very carefully that he who was mild at his ascent will be terrible at his return'. ${ }^{10} \mathrm{He}$ urged all his congregation, his correspondents and even the Emperor Maurice, not to be complacent about the judgement of almighty God: 'For we do not know as yet what future each has there ... And there are many things which men do not know about His judgment, for perhaps he condemns what you praise, and what you condemn, he will praise. ${ }^{11} \mathrm{He}$ did not exempt himself, having already

\footnotetext{
${ }^{5}$ See Martyn, Letters, pp. 51-8.

${ }^{6}$ Markus, Gregory the Great, pp. 100-6.

${ }^{7}$ The flooding of Rome (and Verona, though the latter was less severe) was mentioned by Pope Gregory and his contemporary Gregory of Tours, and elaborated by later writers as an unprecedented event presaging the horrors to come. Paolo Squatriti has argued, however, that these descriptions should be read in their literary and spiritual contexts, not treated as evidence of a 'catastrophic meteorological event'. 'The Floods of 589 and Climate Change at the Beginning of the Middle Ages: An Italian Microhistory', Speculum 85 (2010), p. 804.

${ }^{8}$ Brian E. Daley, The Hope of the Early Church (Grand Rapids, MI: Baker Academic, 2010), pp. 211-4.

'Jane Baun, 'Gregory's Eschatology', in Bronwen Neil and Matthew dal Santo (eds), Companion to Gregory the Great (Leiden: Brill, 2013), pp. 157-76.

${ }^{10}$ HEv. 29.11, SC 522 (2008), p. 218: Et hoc nobis magnopere perpendum, quia is qui placidus ascendit terribilis redit ... 'Homily 29', Gregory the Great, Forty Gospel Homilies, trans. David Hurst (Collegeville, MN: Cistercian Press, 1990), p. 234.

${ }^{11}$ The letter was written in reply to sharp criticism by Maurice when Gregory took independent action against the Lombards. Ep. 5.36, June 595. MGH 1, 320.12: Nam adhuc nescimus, quis ibi qualis sit ... Et sunt multa quae de iudicio illius homines ignorant, quia fortasse quae vos laudatis, ille reprehendit, et quae vos reprehenditis, ille laudabit. ET: Martyn, Letters, p. 349.
} 
described himself in the same letter as 'human and a sinner', who 'daily transgressed against God'. 12

Towards the end his life, as the military threats appeared to be easing, Gregory did not seem to feel the same eschatological urgency, but his pastoral anxiety about the ultimate judgement of each individual remained intense. In a letter to Ethelbert, "king of the English', in June 601, he praised him for supporting the spread of Christianity, which should help him when facing 'the terrifying Judgment of almighty God'. ${ }^{3}$ Gregory then described the portents for the end of the world, such as tempests, wars, famines, plagues and earthquakes. Although he reassured Ethelbert that he did not think the end would come 'in our days', he emphasised that these events should be interpreted as signs that the end would come soon and that 'we ought to be worried about our souls'. ${ }^{14}$ Gregory was particularly concerned about the souls of those who defied the unity of the Catholic church by denying its interpretation of Chalcedon.

\section{Unity of the church}

Gregory had to deal with a number of schisms and heresies, some historic, some new, and his letters are peppered with references to the challenges they posed to the unity of the church. ${ }^{15}$ The one he could do least about was Arianism, as the Arian Lombards consolidated their power base in northern Italy. The issue that caused him the most persistent concern, however, was the Istrian schism, provoked by the Fifth Ecumenical Council of 553. This is explored in depth because it provides the clearest evidence of the link Gregory made between Chalcedon and church unity, and therefore helps to illustrate Chalcedon's role in the West after 553. It also challenges Grillmeier's assumption of a 'single-minded but uncomplicated trust in Chalcedon' between 553 and 604 .

The Fifth Council (also known as the second Council of Constantinople) had been summoned by the Emperor Justinian, who wanted to emulate Constantine and reunite the eastern and western parts of his empire through the acceptance of one statement of faith. ${ }^{16}$ In theory the Council of Chalcedon of 451, as the fourth of the ecumenical councils (following Nicaea in 325, Constantinople I in 381 and Ephesus I in 431), had fulfilled this function. In practice Chalcedon had always been divisive, particularly in the East. Chalcedon's definition of Christ had, however, been generally accepted in the West, as it incorporated terminology formulated by Pope Leo in his Tome to

\footnotetext{
${ }^{12}$ Ep. 5.36. MGH 1, 319.1: Ego enim homo peccator sum ... quia omnipotenti Deo incessanter cotidie delinquo ...

${ }^{13}$ Ep. 11.37. MGH 2, 309.11: omnipotentia Dei terribile examen. ET: Martyn, Letters, p. 783.

${ }^{14}$ Ep. 11.37. MGH 2, 309.29: quae idcirco haec signa de fine saeculi praemittuntur, ut de animabus nostris debeamus esse solliciti ... ET: Martyn, Letters, p. 784.

${ }^{15}$ Martyn provides a list in the index and gives details when each is mentioned. Some are well known, like Donatists and Nestorians; others are obscure, like the angelii in North Sicily mentioned in Ep. 3.59 (August 593), who might have been angel worshippers, pagans or Sabellians (MGH 1, 218.18; ET: Martyn, Letters, p. 279). Pagans were active in Gaul: see Ep. 8.4 (Sept. 597) to Brunhilde, and Martyn's note 43 (MGH 2, 209.21; ET: Martyn, Letters, p. 501).

${ }^{16}$ This is a simplified summary of a complex situation, based mainly on the indispensable analysis and documentation provided by Richard Price, Acts of the Council of Constantinople of 553: With Related Texts on the Three Chapters Controversy, 2nd edn (Liverpool: Liverpool University Press, 2012); see the sections on the Three Chapters, I. 16-17, 76-98 (n.b. this one-volume edition retains the pagination of the 2-vol. original). See also Markus, Gregory the Great, pp. 125-42.
} 
Flavian. The key phrases were that Christ was 'the same perfect in Godhead, the same perfect in manhood, truly God and truly man ... to be acknowledged in two natures, without confusion, without change, without division, without separation'. ${ }^{17}$

Chalcedon was widely challenged in the East by the miaphysites, who argued that Christ had one nature, but both divine and human attributes. ${ }^{18}$ They criticised Chalcedon for not properly incorporating the teaching of Cyril of Alexandria and for accommodating the ideas of Nestorius, whom they accused of separating the Godhead and humanity of Christ into two distinct persons. They were concerned not only with the definition, but the fact that in its disciplinary sessions the Council of Chalcedon had readmitted to the church three writers who had previously been excommunicated because of their alleged Nestorianism: Theodoret of Cyrrhus, Ibas of Edessa and (posthumously) Theodore of Mopsuestia.

Miaphysite influence had grown strongly in the East in the early sixth century. Justinian (himself a keen theologian) determined to resolve the divisive issue by reconfirming the core christology of Chalcedon, but rejecting its decisions to reinstate the trio. He first tried to do this in 544/5 through an edict (now lost) which condemned the three theologians and their relevant writings, which collectively became known as the 'Three Chapters'. Neither this edict, nor a subsequent one of 551 were accepted, so Justinian decided to call an ecumenical council. To make any decision valid for the whole empire, Justinian needed the agreement of the West, as represented by Pope Vigilius (r. 537-55), although Vigilius had adamantly opposed the condemnation of the Three Chapters. He had already been forcibly brought to Constantinople in 547 and was eventually coerced into agreeing to the Fifth Council's decrees in 553. The Fifth Council formally upheld the doctrinal statement of Chalcedon and the three preceding ecumenical councils as inviolable, and duly condemned the Three Chapters. ${ }^{19}$

The official papal line after the Fifth Council of 553 supported the position ultimately agreed by Vigilius. Thus the Fifth Council's condemnation of the Three Chapters was deemed valid. Although this initially provoked hostility in some parts of West, Vigilius' successors effectively neutralised opposition except for Northern Italy. $^{20}$

\footnotetext{
${ }^{17}$ Pope Leo I (r. 440-61) had sent a letter, usually referred to as his Tome to Flavian, the bishop of Constantinople (r. 446-9), which was then submitted to the second (non-ecumenical) Council of Ephesus of 449. His letter was ignored there, but its key definition of Christ was then integrated into the Chalcedonian definition in 451: 'Wherefore, following the holy Fathers, we all with one voice confess our Lord Jesus Christ one and the same Son, the same perfect in Godhead, the same perfect in manhood, truly God and truly man, the same consisting of a reasonable soul and a body, of one substance with the Father as touching the Godhead, the same of one substance with us as touching the manhood, like us in all things apart from $\sin . .$. to be acknowledged in two natures, without confusion, without change, without division, without separation ... 'The Chalcedonian Definition of the Faith', in J. Stevenson and W. C. Frend (eds), Creeds, Councils and Controversies (London: SPCK, 1989), p. 352.

${ }^{18}$ Price, Constantinople, II. 311: 'Miaphysite Christology ... rejects the Chalcedonian formula of two natures in Christ, and insists that he is one nature, in the sense of a single being, albeit possessing both divine and human attributes.' Miaphysite is replacing monophysite as a description of this type of non-Chalcedonianism in academic writing.

${ }^{19}$ Price comments that the agreement between Justinian and Vigilius that enabled this outcome lowered the relations between the head of state and the primate of the Church to the level of a deal between gangsters'. Price, Constantinople, II. 74.

${ }^{20}$ Ibid., I. 30-3.
} 


\section{Schism in north Italy and Istria}

The powerful sees of Milan and Aquileia, traditionally resistant to the authority of Rome, refused to accept the Fifth Council's legitimacy because, they argued, Chalcedon must be accepted in its entirety. They therefore broke off communion with Rome. The situation was further complicated by successful Lombard invasions in the area from 568, including the capture of Milan. The bishop, Honoratus, who supported the schism, sought refuge in Genoa in 569; but his successor, Laurence, rejoined the Catholic church in 573. As the new bishop's only source of revenue was now in Sicily and therefore controlled by Rome, Laurence signed a formal arrangement whereby Rome had jurisdiction over the Milanese see. ${ }^{21}$ In contrast, the schism in Aquileia became entrenched.

In 585 a truce was arranged between the emperor Maurice and the Lombards. This enabled Pope Pelagius II to try to resolve the schism. He sent three letters to the schismatic bishop Elias of Aquileia and his fellow bishops. The third one was very probably drafted by Gregory on Pelagius' behalf. ${ }^{22}$

These letters are good evidence for the totemic significance of Chalcedon as the definitive summation of the Catholic faith, reaffirming and completing the statements of Nicaea, Constantinople I and Ephesus. Letter 1 cites all four previous councils plus the Tome of Leo. Anyone who presumes to teach anything contrary to the faith according to the fathers is damned and anathematised. ${ }^{23}$ Pelagius urges the Istrians to come together as 'one flock in the breast of the mother church'. ${ }^{24}$ Letter 2 expresses regret at the negative response to Letter 1 (this response has been lost), and at the continued scandal of the division. ${ }^{25}$ It offers a 'let-out' clause, suggesting the schismatics clearly did not know that the holy fathers had said that Chalcedon was the inviolable definition of faith. ${ }^{26}$ If they persisted, there would be no excuse at the day of judgement. ${ }^{27}$ The letter closes with a final warning: the sheep who stray from the sheepfold of the church will be eaten by the teeth of the rapacious wolf. ${ }^{28}$

Letter 3 is much longer: twenty pages compared to three pages in each of Letters 1 and 2 in the Schwartz edition. ${ }^{29}$ It supports the decision of the Fifth Council with extensive details from the writings of the Three Chapters to show it had been correct in con-

\footnotetext{
${ }^{21}$ Markus, Gregory the Great, p. 134.

${ }^{22}$ Paul Meyvaert, 'A Letter of Pelagius II Composed by Gregory the Great', in John C. Cavadini (ed.), Gregory the Great: A Symposium (Notre Dame, IN: Notre Dame University Press, 1995), ch. 6. Meyvaert convincingly demonstrates Gregory's authorship from verbal and stylistic differences between the first two letters and the third.

${ }^{23}$ Schwartz, ACO 4.2, 106.21: Si quis autem contra hanc fidem aut sapit aut credit aut docere praesumit, secundum eorundem partum sententiam damnatum atque anathematizatum se esse cognoscat.

${ }^{24}$ Schwartz, ACO 4.2, 108.17: ut in sinu matris ecclesiae congregati efficiamur unus grex.

${ }^{25}$ Schwartz, ACO 4.2, 108.41: diuisionis scandalum.

${ }^{26}$ Schwartz, ACO 4.2, 109.22: ut evidentius agnoscatis quia sancti patres nihil aliud de Chalcedoniensis synodo in suis epistolis firmauerunt nisi ut inuiolabilis fidei definitio seruaretur.

${ }^{27}$ Schwartz, ACO 4.2, 110.11: quando in die iudicii nullus uestrum excusare se ualeat...

${ }^{28}$ Schwartz, ACO 4.2, 112.14: oues a saeptis ecclesiasticis euagantes rapacis lupi dentibus consumantur.

${ }^{29}$ Letter 3 has been extensively analysed by Meyvaert, as noted in note 22 above, and also by Carole Straw in 'Much Ado About Nothing: Gregory the Great's Apology to the Istrians', in Celia Chazelle and Catherine Cubitt (eds), The Crisis of the Oikoumene: The Three Chapters and the Failed Quest for Unity in the Sixth-Century Mediterranean (Turnhout: Brepols Publishers, 2007), pp. 121-60. I focus here on its use of Chalcedon.
} 
demning them. ${ }^{30}$ In his defence of Vigilius, whose change of mind had prompted the schism, Gregory anticipated the statement attributed to John Maynard Keynes: 'When the facts change, I change my mind':

If in the matter of the Three Chapters one position was held while truth was being sought, and a different position was adopted after truth had been found, why should a change of position be imputed a crime to the See which is humbly venerated by all in the person of its founder? [i.e. Peter, previously cited as one who changed his mind]. For what is reprehensible is not to change one's stand, but to entertain fickle opinions. Now if the mind remains unwavering in seeking to know what is right, why should you object when it abandons its ignorance and reformulates its position? ${ }^{31}$

But the heart of the letter was its defence of the definition of the faith embodied in Chalcedon and endorsed by the papacy. It goes to exhaustive lengths to show Chalcedon's alignment with Leo, and subsequently Leo's own alignment with Chalcedon, demonstrated by various letters he wrote, such as one to Bishop Basil of Antioch. This urged Basil and his fellow bishops to reject any change to what had been divinely inspired, because 'the whole Christian religion would be in turmoil if any of these matters agreed at Chalcedon were disturbed'. ${ }^{32}$

As in the two previous letters from Pelagius, the theological necessity for church unity is emphasised in Letter 3. The church is compared to the sun: 'The holy and universal church beams the rays of its unity in all parts of the world, but has to endure the shadow of your division. ${ }^{33}$ It repeats the warning that the Istrian schismatics would be in danger of eternal punishment if they persisted, quoting from the epistles of Paul and citing Cyprian and Augustine to reinforce the point that 'while you separate yourselves from the unity of the church you will lose all reward'. It then concludes with an exhortation to return to 'the pure faith of the holy synod of Chalcedon'. ${ }^{34}$

Gregory reiterated these arguments after he became pope in 590. In February 591 he sent a letter to fellow patriarchs proclaiming his faith, as was customary for newly elected patriarchs. He concluded by affirming that he venerated the four councils, 'just like the four books of the Holy Gospel'. He gives a brief clause describing each one, not in terms of theology but in terms of the heretics they condemned: the perverse error of Arius at Nicaea, the errors of Eunomius and Macedonius at Constantinople 1,

\footnotetext{
${ }^{30}$ Straw deconstructs the letter as 'a rhetorical yarn, entangling every issue in a web of fact and fiction', and criticises Gregory as 'a politician who would sacrifice candor to expediency'. This does not take into account that (1) he was writing on behalf of the pope, and (2) he firmly believed that the immortal souls of the schismatics were at stake.

${ }^{31}$ Schwartz, ACO 4.2, 119.18: Si igitur in trium capitulorum negotio aliud cum veritas quarereretur, aliud autem inventa veritate dictum est, cur mutatio sententiae huic sedi in crimine obicitur, quae a cuncta ecclesia humiliter in eius auctore venerator? Non enim mutatio sententiae, sed inconstantia sensus in culpa est. Quando ergo ad cognitionem recti intentio incommutabilis permaneat, quid obstat, si ignorantiam suam deserens uerba permutet? ET: Meyvaert, 'A Letter of Pelagius II', p. 104.

${ }^{32}$ Schwartz, ACO 4.2, 116.23: tota religio Christiana turbatur, si quicquam de his quae apud Chalcedonam constituta sunt, conuellatur.

${ }^{33}$ Schwartz, ACO 4.2, 113.3: Ecce in cunctis mundi partibus sancta et uniuersalis ecclesia unitatis suae radiis fulget, sed tamen adhuc umbram uestrae divisionis sustinet.

${ }^{34}$ Schwartz, ACO 4.2, 132.22: quia dum vos ab ecclesiae unitate disiungitis, omne virtutis meritum perdidit; 132.30: fidem sanctae Chalcedoniensis inlibatam per omnia deo auctore.
} 
the impiety of Nestorius at Ephesus, and the depravity of Eutichius and Dioscorus at Chalcedon. Then he adds: 'I also venerate equally the fifth council, in which are refuted ...' and summarises the faults of Ibas, Theodore and Theodoret. ${ }^{35}$

After 591, rather than mentioning the Fifth Council, Gregory more often sought unity through emphasis on a positive commitment to Chalcedon, even though he had previously argued that upholding its condemnation of the Three Chapters was central to church unity. In 592, to demonstrate that the church's commitment to Chalcedon had not changed, he sent a copy of Pelagius' (i.e. his) Letter 3 in response to a request from all of the eastern bishops, who had asked for support against persecution by the Lombards. He admonished them to 'reread it frequently with pure and vigilant hearts'. ${ }^{36}$ There was no justification for the schism, he argued, because 'in the synod which dealt with the Three Chapters [i.e. the Fifth Council, but not named] ... nothing to do with faith was cancelled or changed at all' ${ }^{37} \mathrm{He}$ concluded with the threat that they would not be saved, because they were outside the true church. He therefore urged them to lay aside their pride and return to the mother church. ${ }^{38}$

The consequences of the schism reappear throughout Gregory's papacy, mainly in connection with the clerics in the diocese of Milan. After the death of Laurence in 593, this group had to elect a new bishop and chose Constantius. He was soon challenged by three schismatic bishops for having condemned the Three Chapters (i.e. rejecting Chalcedon, as they interpreted it) when he had been in Rome earlier. Gregory's response was interesting. He made no mention of the Fifth Council in the two relevant letters. He said he had no recollection of the Three Chapters being discussed in letters or conversation with Constantius, but he trusted him without a pledge. $^{39}$ However, the key point was adherence to Chalcedon (as the Catholic Church interpreted it): 'For with Truth guiding us and with conscience our witness, we confess that we preserve the faith of the holy synod of Chalcedon as inviolate in every way, and dare to add nothing, and to subtract nothing from its definition.' $\mathrm{He}$ therefore urged the dissident bishops to heed his warning, 'and not to divide themselves from the body of Christ which is the holy, universal church'. 40

Gregory reiterated this in a letter, also from September 593, to Theodelinda, the Catholic wife of the Lombard (and Arian) king Agilulf, who had been persuaded to support the schismatics. Again he did not refer to the Fifth Council by name. He refuted

\footnotetext{
${ }^{35}$ Ep. 1.24, Feb. 591. MGH 1, 136.26: Quintum quoque concilium pariter veneror (Martyn, Letters, p. 146).

${ }^{36}$ Ep. 2.43, July 592. (The letter is dated Aug. 592 and numbered 2.49 in MGH.)

${ }^{37}$ Ibid. MGH 1, 151.5: Nam in synodo, in qua de tribus capitulis actum est, aperto liquet, nihil de fide convulsum esse, vel aliquatenus inmutatum.

${ }^{38}$ MGH 1, 151.28: Unde iterum habita compassione caritatem ammoneo, ut quoniam Deo suffragante fide nostra integritas in causa trium capitulorum inviolata permansit, mentis tumore deposito tanto citius ad matrem vestrum ... ecclesiam redeatis... 'Therefore, I again warn your Charities with customary, compassion, since with God's favor the integrity of our faith remains inviolate in the case of the Three Chapters, lay aside your pride and return all the more quickly to your mother church ... ' ET: Martyn, Letters, p. 222.

${ }^{39}$ Laurence had sent a witnessed pledge to uphold the Fifth Council's condemnation. Ep. 4.2, Sept. 593 (MGH 1, 233; Martyn, Letters, p. 287), sets out the situation in detail.

${ }^{40}$ Ep. 4.3, Sept. 593. $M G H$ 1, 235.19: Nos enim auctore Veritate, teste conscientia fatemur, fidem sanctae Chalcedonensis synodi inlibatam per omnia custodire nihilque eius definitioni addere, nihil subtrahere audere ... seque a Christi corpore, quod est sancta universalis ecclesia, non dividant. ET: Martyn, Letters, p. 289.
} 
the schismatics. as 'ignorant and foolish people' who falsely claimed that in Justinian's time 'some things had been decided contrary to the synod of Chalcedon':

For we confess with our conscience that nothing has been removed from the faith of that same holy council of Chalcedon, nor anything violated; However, whatever was done at the time of the aforementioned Justinian, was done in such a way that the faith of the council of Chalcedon might be disturbed in no way. ${ }^{41}$

Neither does Gregory mention the Fifth Council in a letter he wrote to the bishops of Gaul in 595, urging them to preserve 'the integrity of the Catholic faith, that is of the four holy synods'. 42

The Fifth Council is mentioned, however, in the letter sent to Theodelinda from December 603, when Gregory wrote to congratulate her on the birth of her son. He sent a copy of the Fifth Council's proceedings with it. The copy was not intended for Theodelinda, however, but for an abbot, Secundus, who had asked for more information on the schism and Three Chapters. Secundus was urged to reread the statement of the Fifth Council 'and acknowledge the falsity of all the things that he had heard against the apostolic see and Catholic Church'. But again, Gregory emphasised that it was the four previous councils which were the key to faith, because 'we accept whatever was decided by the four holy synods, and we condemn whatever was rejected'. ${ }^{43}$

The letters show that what was at stake for Gregory and the schismatics in the Istrian schism was not the core belief of Chalcedon, but whether the doctrinal statements alone, or the whole of its proceedings, were inviolable. Gregory's response provides clear evidence that for him, as the pope's deacon and then as pope himself, the necessary condition for church unity was adherence to the former, accompanied by recognition that the subsequent decision of the Fifth Council was also valid.

These letters confirm that Chalcedon, as narrowly interpreted, remained the touchstone of a unified faith in the Catholic church of the late sixth century. Gregory's other writings give a clearer indication of how he interpreted the definition of Christ which lay at its heart.

\section{Defining the two natures of Christ}

Gregory was not a systematic theologian in the modern sense, nor an original thinker in comparison with Augustine, from whom many of his theological statements ultimately derive. This is not surprising, given the circumstances in which he lived and his responsibilities as pope. ${ }^{44}$ A full analysis of Gregory's response to the theology of Chalcedon is beyond the scope of this article, but it seems he was not concerned with exploring the metaphysical concepts which lay behind the core Chalcedonian definition of the two

\footnotetext{
${ }^{41}$ Ep. 4.4, Sept. 593. MGH 1, 236.15: Nos enim teste conscientia fatemur, de fide eiusdem sancti Chalcedonensis concilii nihil motum, nihil esse violatum. Sed quicquid praedicti Iustiniani temporibus actum est ita actum est, ut fides Chalcedonensis concilii in nullo vexaretur. ET: Martyn, Letters, p. 289.

${ }^{42}$ Ep. 5.59, Aug. 595. MGH 1, 373.3: quatenus est catholicae fidei integritas, id est sanctarum quattuor synodorum. ET: Martyn, Letters, p. 394.

${ }^{43}$ Ep. 14. 12, Dec. 603. MGH 2, 431.24: sed quaecumque a sanctis quattuor synodis sunt definata, recipimus et, quaecumque reprobata sunt, condemnamus. ET: Martyn, Letters, p. 878.

${ }^{44}$ Jean Laporte argues that Gregory was in fact original in his exploration of the theme of suffering. See 'Une théologie systematique chez Grégoire?' in Jacques Fontaine (ed.), Grégoire le Grand (Paris: CNRS 1986), p. 236.
} 
natures of Christ. ${ }^{45}$ Gregory's formal writings focused instead on the pastoral task of explaining to various audiences that their ultimate salvation depended on this duality. He echoes the actual phrasing of the definition in some of his statements about Christ. Chalcedon's summary 'in two natures, without confusion, without change, without division, without separation' clearly lies behind Gregory's Homily 1.8 on Ezekiel, where he tells his congregation that, 'In our Savior, then, the natures of divinity and humanity are united and joined without confusion'. ${ }^{46}$ Similarly, in his preface to Moralia in Job, he asks, "what is it to say, "the Lord God", but to believe that he is both God by his divinity and to declare that he is Lord through his incarnation? ${ }^{47}$

Amongst Gregory's favourite terms for Christ were 'Mediator' and 'Redeemer', sometimes interchangeably. These terms are particularly prominent in Moralia in Job. This 35-volume work was written at the request of his monastic community in Constantinople, and was revised and completed when Gregory became pope in 590 . Although nominally an exegesis on the Book of Job, the work is in one sense a prolonged exploration and explanation of the work of salvation through Christ and the church. Gregory explains in the preface that Job represents Christ as 'the type of the Redeemer who was to come, as his name shows. For Job means "sufferer". And this suffering expresses clearly both the passion of the Mediator and the work of the holy church ...'48 Gregory later explains that, 'as God, Christ is our Redeemer, and gives all things with the Father; but as Man, he receives certain things from the Father'. ${ }^{49}$

Throughout his work, Gregory emphasised the physical reality of Christ's human body and argued that Christ retained that reality after the resurrection and ascension. In his Gospel Homily 29 on the ascension, Gregory described Christ as 'a human being on high': 'When he was born his divinity seemed to have been humbled, while when he ascended his humanity was exalted ... he who appeared as God made humble at his birth was revealed in his ascension as a human being on high. ${ }^{50}$

Gregory argued that our own bodies would also be somehow corporeal in the next life. A key text was Job 19:25-7: 'I know that my Redeemer lives, and that at the last he will stand upon the earth ... then in my flesh I shall see God' (NRSV). Gregory expounded the text by describing his only recorded theological debate, in 582 in Constantinople with the elderly patriarch Eutychius (who by coincidence had chaired the Fifth Council in 553). Gregory was challenging Eutychius' argument that the

\footnotetext{
${ }^{45}$ See Bernard Green, 'The Theology of Gregory the Great: Christ, Salvation and the Church', in Companion to Gregory the Great, pp. 135-56. The role of Christ as God and man is analysed in depth by Carole Straw, Gregory the Great: Perfection in Imperfection (Berkeley, CA: University of California Press, 1988), pp. 147-61.

${ }^{46} \mathrm{HEz}$. 1.8.25. SC 327 (1986), p. 312: In Redemptore autem nostro natura diuinitatis et humanitatis inconfuse unita sibimet atque coniuncta es. ET: Theodosia Tomkinson, Homilies on the Book of Ezekiel (Etna, CA: Center for Traditionalist Orthodox Studies, 2008), p. 150.

${ }^{47}$ Moralia, Praef. 19. SC 32 (1950), 140: Vel quid est, Deum Dominum dicere, nisi hunc et Deum per divinitatem credere et Dominum ex incarnatione perhibere?

${ }^{48}$ Moralia, Praef. 16. SC 32 (1950), 137: Nam quia beatus Job venturi Redemtoris [sic] speciem teneat, etiam nomine demonstrat. Job quippe interpretatur dolens. Quo nimirum dolore, vel Mediatoris passio, vel sanctae Ecclesia labor exprimitur.

${ }^{49}$ Moralia, 2.60. SC 32 (1950), 225: Redemtor [sic] noster per hoc quod Deus est, cum Patre dat omnia: per hoc vero quod homo est, a Patre accipit inter omnia.

${ }^{50}$ HEv. 29.9. SC 522 (2008), 214: Quia nascente Domino uidebatar diuinitas humiliata, ascendente uero est Domino humanitas exaltata. ... quia qui in natiuitate sua apparuit Deus humilis, in ascensione sua ostensus est homo sublimis. ET: Hurst, Forty Gospel Homilies, p. 232.
} 
resurrected body would be 'impalpable, more subtle than the wind and the air'. ${ }^{51}$ Gregory won the debate. Gregory was told later by friends that Eutychius changed his mind on his death-bed, and showed them the skin of his hand, saying 'I confess we will rise again in this flesh. ${ }^{52}$

This was a threat as well as an encouragement. The Redeemer and Mediator was also the Judge. Gregory described Job/Christ as rising from the dead to administer justice to the wicked. ${ }^{53}$ Only those who recognised the darkness of their sin would be filled with the fire of his love. ${ }^{54}$ As we have seen in his letters, Gregory was ever mindful of the 'the terrifying judgment of almighty God'. ${ }^{55}$

\section{Conclusion}

Gregory's references to Chalcedon challenge Grillmeier's depiction of the West between 553 and 604 as having 'a single-minded but uncomplicated trust in Chalcedon'. From the Fifth Council of 553 to Gregory's death in 604, Chalcedon was the cause of bitter dispute. The continuing Three Chapters controversy highlighted the problem of interpretation. Did 'Chalcedon' mean its doctrinal statements alone (the official imperial and papal stance), or should it be understood as a complete package (the Istrian schismatics)? Gregory's correspondence shows there were also many groups of 'heretics' even in the West who rejected Chalcedon outright. Gregory continued the arguments of his papal predecessors, but with the added urgency of intense anxiety for the salvation of his people as the end of the world rapidly approached (or so he believed). Salvation for Gregory depended on faith in Chalcedon's definition of the divine and human natures of Christ, but also on church unity, which was as elusive when he died in 604 as when he became pope. His enduring legacy, however, is not based on his convoluted arguments against the schismatics, but on his insistence on the pastoral significance of the Chalcedonian definition of Christ.

\footnotetext{
${ }^{51}$ Examined in detail by Yves-Marie Duval, who suggests it must have been a long-running theological dispute. Gregory's arguments were favoured by the emperor Tiberius, who ordered the books of Eutychius to be burnt. See 'La discussion entre L'apocrisiare Grégoire et le patriarche Eutychios au sujet de la resurrection de la chair', Grégoire le Grand, pp. 347-65.

${ }^{52}$ Moralia, 14.74. SC 212 (1974), 438: Confiteor quia omnes in hac carne resurgemus.

${ }^{53}$ Moralia, 2.55. SC 32 (1950), 221: Redemtor [sic] humani generis semetipsum a carnis suae mortis suscitavit: quanto judicio persecutores suos deseruit, demonstrauit.

${ }^{54}$ Moralia, 2.57. SC 32 (1950), 223: peccatorum vero suorum tenebras agnoscentibus, igne sui amoris infulsit.

${ }^{55}$ See note 13 above.
}

Cite this article: Sidaway J (2020). The reception of Chalcedon in the West: a case study of Gregory the Great. Scottish Journal of Theology 73, 307-317. https://doi.org/10.1017/S0036930620000630 